\title{
A SPECULATIVE APPROACH TO DRAMA, TIME AND COSMOS
}

\author{
Nuri NALBANTOĞLU ${ }^{1}$ \\ 1 Dr. Öğr. Üyesi, İstanbul Gelişim Üniversitesi, nnalbantoglu(at)gelisim.edu.tr, ORCID: 0000-0003-3629-2212
}

Nalbantoğlu, Nuri. “A Speculative Approach to Drama, Time and Cosmos”. idil, 60 (2019 August): s. 985-989. doi: 10.7816/idil-08-60-04

\begin{abstract}
Drama, both as an artwork and as a micro cosmos, is built on 'the meaning (idea) '. The meaning for human consciousness cannot be considered independent of space-time. Therefore, the art of drama is open to all kinds of speculation about the phenomenon of time. In order to understand the structure of the cosmos, we make observations, experiments and analyses and produce theories by means of science and philosophy and at the end of these theories we get some explanations and concepts; such as paradoxes, entropy and big bang. In this study, a speculative approach is tried to be brought to the story of Oedipus by making use of scientific interpretations of concepts such as time, entropy and big bang. The history of the Oedipus has a beginning that expresses "the absolute order". This beginning reminds us of the universe before the big bang. With the realization of a prophecy, this "absolute order" will evolve into chaos, and the destruction of Oedipus will begin over a long period; just like the continuous expansion of the universe, the increase of disorder, namely entropy, a theory of physics. In the fictional universe of Oedipus, the restoration of order can only be achieved by the death of Oedipus. The situation is the same in the universe we live in: For the end of chaos and the establishment of the absolute order, all the matter that constitutes the universe must be collected into a single point, which means that the universe returns to its starting point.
\end{abstract}

Keywords: Drama, Time, Cosmos, Oedipus, Entropi, Big Bang 


\section{Introduction}

We encounter 'structures' when we examine the universe. Everything, from galaxies to tiny atoms, has a structure. We can tell that the 'understanding' we have of these substances is proportional to what we can explain about these 'structures'. In works of art, also, perceiving the 'structure' and analyzing it will lead to understanding the work. The structure is also the basis of art. There is no art without a structure. Both the universe and art have structures. Art can be defined in a number of ways, but the most inclusive definition is this: Art is an alternative universe! Universes that have existed, universes that are too impossible to exist, imaginary universes and universes that can't even be imagined... Now, art is about creating these universes. An artist is a master builder of structure that constructs an artwork; these 'universes'.

\section{Drama, Time and Cosmos}

Drama also has a structure. What Aristotle tries to do in his Poetics is to explain this structure. Aristotle has examined the structure and made suggestions regarding it. For Aristotle, this structure consists of the story, the space and the time. The story (mythos) contains the characters and the events, where space and time are other dimensions of this universe. Another important phenomenon that helps us to comprehend the structure of both the drama and the universe is the concept of "time".

Time is a subject of philosophical speculations about time wrote different writers and philosophers of the past and present. What were the main questions? Does time really exist? Is it illusion or a substance? For example, Zeno considered that time is connected with movement and he supposed that movement is an illusion. In our daily experience we believe that time exists, because we cannot imagine our life out of time, everything exists and changes in time - sun rises, seasons change etc.

The phenomenon, which makes us understand the concept of time, is the matter. Time is a magnitude that is identified as a space where matter exists in time continuum. The units of time are used to measure movement of objects, life, history... For example, within the classical (Newton) physics if one knows the data at the moment of a ball tossed upward, one can calculate its exact height after any moment. Therefore, time constant of Newton is based on certitude; which means that everything can be predicted and calculated in his world. $\mathrm{He}$ is a determinist, and time is the most reliable and constant building block of this determinism. In the world of low velocity, that is to say in human life, in observable universe we have a perception that time progresses in constant speed. Within this scope, we think that time advances everywhere with the same speed; however, our conception of time will change as we pass to modern physics. Newton Physics that is valid in low velocity breaks down as we approach to the speed of light. From now on, time is no longer a phenomenon accelerating at constant rate, but a variable dependent on mass and velocity. For example, when we move at the speed of light, we can no longer mention the progression of time. In these circumstances, time is not absolute but relative.

As we remember the twin paradox, one of the identical twins makes a journey into space at the speed of light and returns home to find that the twin who remained on Earth has aged thirty years more than him. According to Modern Physics time is relative; that is to say, in different speeds flow of time dramatically changes. On the other hand it is certain that perception of time is subjective what means that we do not always perceive the flow of time as a constant phenomenon. In some cases it seems to us that time accelerates too quickly, for example, when we are getting ready for an important exam or when we're having fun and are happy. In a manner, time decelerates when we focalize on it and accelerates when we're unaware of it. Even though these examples rely on personal experiences and perceptions, they give us opinion about the nature of time.

Time measurement informs us about "the place "and subsequence of events and happenings in the flow of time. These are two things entirely related to time concept. How can we understand which one of two incidents took place first? First of all we should agree that time advances straightly from past to future and all events and phenomena are included in it. The only problem here is to define what happened earlier and what later. In physics the realization of two events will be aligned by 'entropy' 2 Aristotle explains the task of subsequence by category of reason and action. Action could be understood as a logical chain of

2 Entropy: Entropy is a term of thermodynamic that represents in physics, the thermal energy of a system, which cannot be transmitted into mechanical work. It is the second law of thermodynamics and defined as irregularity. As the regularity (density) is at its maximum level before the big bang, entropy is zero. After the big bang entropy, which means irregularity, starts to escalate. 
related events.

Can we use the physical method in drama analysis? We suppose that it is possible. We try to explore the dramatic events through the concept of entropy. The level of entropy depends on the time passed from the initial explosion (big bang)3. The farther we are the more entropy is. We presume that the more irregular events take place later. To imagine what we mean we can bring an example of a perfume and the level of entropy in three different cases. In the first case (before big bang) perfume is closed in a bottle and the level of entropy is very low. In the other case we spray perfume in one room of three room house. Now the level of entropy is higher. In the third case we smell perfume spread in each room of the three room house - here we have the highest level of entropy. So the level of entropy indicates how close we are to the initial point, the exposition or initial stage of a big bang.

As we noted we can compare the initial condition of events in drama to the condition of matter before big bang as well as with a bottle of perfume before it's opened. The universe continues to expand, to advance towards the disorder from the absolute order after the big bang. Theory of entropy suggests also that time is unidirectional- time flows one direction. We cannot put back into the tube the toothpaste after it has been squeezed. All the incidents can be put into an order of precedence with the entropy. Theatre scripts can also be interpreted in this direction. In fact, incidents in the script advance in harmony until the climax or the peripeteia (big bang). Starting from this point (climax), disorder takes the lead and pursuit of order continues until the end of the play. In this matter, the level of disorder will increase as and when time advances.

For Oedipus, all is well in life, since there is an order. However, disorder runs the show starting from the moment that he comes to know that he has killed his father and then married his own mother. This disorder will continue and accelerate until the "disappearance" of Oedipus.

Polybus, King of Corinth, and Queen Merope love and raise Oedipus as if he was their own child. The

3 Big Bang: The universe was formed by a tennis ball sized sphere (absolute density) that has compressed the basic unit of matter in itself, and the infinite space encircling this sphere. 13.8 billion years ago, this sphere has exploded and the occurring substances have expanded all over the world. This expansion still continues. king and the queen live happily with Oedipus, until one day, a drunken guest treats him like an 'adopted child' during a feast. The next day, the young man asks his parents about this and they both deny it. Oedipus has his doubts, and these doubts would be the beginning of the end. First, the absolute order of Oedipus' universe would collapse... Thereon, Oedipus leaves for Delphi. The prophet predicts a hideous future: Oedipus will lay with his mother, an offspring -a product of adultery- will be born and he will kill his father, the person who gave Oedipus his life. Oedipus, terrified, runs away without knowing where to go, never to return to Corinth again. As he leaves Delphi, he comes across an old man that he doesn't know, riding a cart at a narrow junction with a couple of servants. They dispute over the right of way and in the end; Oedipus kills the old man, which was actually his father. Let's stop and think for a while: What if Oedipus never came across this man? Maybe he would go to another country and live on without any problems. But the big bang happens right at that moment in which he kills his father, and there is no turning back. The order is replaced by disorder that grows day by day. As of this moment, Oedipus' life would move towards disorder, which is chaos. Oedipus dedicates the remaining days of his life to a search of order, wishing for the chaos to end. But is it possible? After the big bang, the universe would expand until its' limit point. Nothing would be able to stop this expansion. The most accepted design of the universe is based upon the idea of it expanding until the border of the universe and then tightening, shrinking due to gravitation until the initial point, the point of big bang. The whole universe has been shrunk into a sphere/ point the size of a single tennis ball, exploded (big bang), expanded, stopped at the limit, tightened and shrunk again until it was as small as a tennis ball once again, thus, completing the cycle of the universe. Disorder has grown with big bang, and then it has shrunk and came back together to a state of absolute order. The structure of tragedies is similar to this. Tragedies begin and grow. Everything is in order during this process. Then, the big bang occurs in climax or peripeteia, the order breaks and disorder starts growing. In the end, the protagonist of the tragedy dies, leading to the construction of a new order (absolute order) both for him and everything else, so the cycle is complete, until a new big bang. This cycle goes on and on.

Let's get back to Oedipus' story. The moment than Oedipus kills his father and marries his mother, just like the universe expanding and reaching its' limit, is 
the moment that Oedipus realizes his destruction. After this destruction, what the protagonist of the tragedy, Oedipus has to do is close his eyes (blinding himself) against this world chaos (disorder) and get away from everyone and everything. The following action of Oedipus is taking the road; he is looking for peace and desires to be alone, what could be explained by his yearning for cosmic order. He wants to get back to way things were before the big bang, to peace and happiness. He does not prefer killing himself like Jocasta, because death means annihilation. Total annihilation does not exist in the universe. We know that the total energy of the universe doesn't change, potential energy turns into motion, solar energy turns into heat. There is no such thing as lost energy. This is true for matters too. Matters don't vanish, they transform into each other. Every substance that forms the universe is made of a determined number of types of atoms. The most significant number in the universe is 10 to the 78th power; which is presumably the total number of all atoms in the universe! (Silk, 2003: 11) That's what Carl Sagan meant when he said "The nitrogen in our DNA, the calcium in our teeth, the iron in our blood, the carbon in our apple pie have all been made in collapsing stars. We are made of starstuff' (Sagan, 2019: 247): You can't destroy something in the universe, you can only change its' structure...

Back to Oedipus's story: 20 years pass. We see Oedipus as a majestic person at the end of his exile despite the fact that he is blind, miserable and about to die. Antigone is a grown woman now, and his most faithful child. They end up in Kolonos, a sacred place. But unhappy Oedipus has no peace in there either. Their sons, Eteocles and Polynices want to manipulate Oedipus and make him go under their tutelage for their own interests. Ismene brings him a word; "If you die without a grave, if nobody knows where you are buried, it will bring them misery and grief. So they want to take you near Thebes, where you can't have your own way" (Sofokles, 2010: 19). Thereon, Oedipus casts out Creon and his own sons with the help of Theseus, King of Athens. Theseus does not reject Oedipus and takes him into his land. Well, how does the story of Oedipus end? Sophocles does not reveal a fine ending for Oedipus. Oedipus is not an ordinary man that could just be buried and forgotten! His end is mysterious. The earth opens up and Oedipus 'disappears' into this gap. We think that he is dead, but this death is no ordinary one, because the death of someone means that this individual vanishes.Yet, the disappearance of Oedipus is a sign of him transforming, passing on to another dimension, and his soul rising up to a sacred level. Oedipus doesn't vanish, he transforms, and thus, he advances towards absolute order, perfection. Every discipline has its' own definition of 'absolute order': For Plato, this is a world of ideas. To me for human life the absolute order is 'death'. Since death signifies the transformation of human form into energy. In astronomy, it's' the 'moment' before the big bang in which entropy is minimal. For religions, it's 'God'. Sophocles must be influenced by Plato, his coeval; that's why we can think that Oedipus has gone towards the world of ideas, in another approach, towards the one and only god. His action, "This way!" (Sofokles, 2010: 54), at the end of the play; can be interpreted as a blind man seeing and perceiving this world of ideas, the absolute order, or god.

\section{Conclusion}

The story of Oedipus, from chaos to absolute order, that is, death, has been transformed into a perfectly constructed artwork thanks to Sophocles. When examining the work of art as an alternative universe, we can incorporate our entire concept repertoire into this process. Science, art and philosophy do not conflict with each other; these disciplines interact, support and nourish each other, and inspire. When we examine the story of Oedipus, we see that this fictional universe created by Sophocles has a cycle; we see that this cycle follows the order of absolute order-chaos-absolute order. If we examine the universe we live in, we see this cycle; the expanding universe will stop at one point, collapse again, and all matter will gather at a single point to reach its original absolute order. So the cycle will be completed. After all we can say that drama as a micro cosmos is also an open space for all of our speculations about the cosmos.

\section{References}

Aristoteles, "Poetika". Çev. İsmail Tunalı. İstanbul: Remzi Yayınları, 2001

Sagan, Carl. "Kozmos". Çev. Reşit Aşçıŏlu. İstanbul: Altın Kitaplar, 2019

Silk, Joseph. "Evrenin Kısa Tarihi”. Çev. Murat Alev. İstanbul: Tübitak Yayınları, 2003

Sofokles. "Oidipus Kolonos'ta”. Çev. Furkan Akderin. İstanbul: Mitos Boyut Yayınları, 2010 


\title{
DRAMA, ZAMAN VE KOZMOSA SPEKÜLATİF BİR YAKLAŞIM
}

\author{
Nuri NALBANTOĞLU
}

$\ddot{O z z}$

Hem bir sanat yapıtı hem de bir micro-cosmos olarak drama 'anlam (idea)' üzerine inşa edilmiştir. İnsan bilinci için anlam; mekan-zamandan bağımsız düşünülemez. Dolayısıyla drama sanatı zaman fenomeniyle ilgili her türlü spekülasyona açık bir alandır. Kozmosun yapısını anlamak için bilim ve felsefe gibi araçlarla gözlem, deney ve analizler yapılır, teoriler üretilir ve bu teoriler sonunda da bazı açıklamalara ve kavramlara ulaşılır: Paradokslar, entropi ve büyük patlama gibi. Bu çalışmada zaman, entropi, büyük patlama gibi kavramların bilimsel yorumlarından faydalanılarak Oidipus'un öyküsüne spekülatif bir yaklaşım getirilmeye çalışılmıștır. Oidipus'un öyküsü "mutlak düzen" ifade eden bir başlangıca sahiptir. Bu başlangıç bize büyük patlama öncesindeki evreni hatırlatır. Bir kehanetin gerçekleşmesi ile bu "mutlak düzen" kaosa evrilecek, Oidipus'un uzun bir sürece yayılan yıkımı başlayacaktır; tıpkı evrenin sürekli genişlemesi, düzensizliğin yani bir fizik kuramı olan entropinin artması gibi. Oidipus'un içinde bulunduğu kurgusal evrende düzenin yeniden sağlanması ancak Oidipus'un ölümüyle sağlanabilecektir. Yaşadığımız evrende de durum aynıdır: Kaosun sona ermesi ve mutlak düzenin sağlanması için evreni oluşturan bütün maddenin tek bir noktaya toplanması gerekir ki bu da evrenin başlangıç noktasına geri dönmesi demektir.

Anahtar Kelimeler: Drama, Zaman, Kozmos, Oidipus, Entropi, Büyük Patlama 